\title{
PERANAN FILSAFAT ILMU DALAM PERKEMBANGAN ILMU HUKUM
}

\author{
Jantarda Mauli Hutagalung
}

Fakultas Hukum, Universitas Bhayangkara Jakarta Raya

jm.hutagalung@dsn.ubharajaya.ac.id

\begin{tabular}{|c|c|c|}
\hline Naskah diterima: & Revisi: & Naskah disetujui: \\
$8 / 07 / 2019$ & $11 / 08 / 2019$ & $20 / 08 / 2019$ \\
\hline
\end{tabular}

\begin{abstract}
Abstrak
Untuk memahami hakikat dari kebenaran, hal terbaik yang dapat dilakukan adalah terus meningkatkan ilmu dengan terus mempertanyakan apa yang telah ada sebelumnya. Inilah yang kemudian menjadi dasar dari berdirinya filsafat ilmu. Dalam usaha mempertanyakan tersebut, manusia memiliki keterbatasan berupa waktu dan kemampuan. Ini menyebabkan belum terungkapnya berbagai keingintahuan manusia. Dengan demikian, usaha manusia untuk memahami jawaban atas pertanyaannya adalah sesuatu yang akan bergerak lambat, tetapi apabila terus dilakukan akan menjadi sesuatu yang berkelanjutan dan dapat membangun kemajuan pengetahuan dan ilmu itu sendiri. Tulisan ini akan membahas mengenai korelasi antara filsafat, hukum dan keadilan dimana hukum tidak dapat dipisahkan dengan masyarakat dan negara, materi hukum digali, dibuat dari nilainilai yang terkandung dalam bumi pertiwi yang berupa kesadaran dan cita hukum cita moral, kemerdekaan individu dan bangsa, perikemanusiaan, perdamaian, cita politik dan tujuan negara.
\end{abstract}

Kata kunci: Filsafat Ilmu, Filsafat Hukum

\begin{abstract}
To understand the nature of truth, the best thing that can be done is to continue to improve knowledge by continuing to question what has been there before. This is what later became the basis of the establishment of the philosophy of science. In an effort to question this, humans have limitations in time and ability. This has caused the unfolding of various human curiosities. Thus, human effort to understand the answer to the question is something that will move slowly, but if it continues to do it will be something that is sustainable and can build on the progress of knowledge and science itself. This paper will discuss the correlation between philosophy, law and justice where the law cannot be separated from society and the state, legal material is extracted, made from values contained in the earth in the form of awareness and ideals of moral ideals, individual and national independence, humanity, peace, political ideals and state goals.
\end{abstract}

Keywords: Philosophy of science, Philosophy of Law 


\section{Pendahuluan}

Sokrates pernah berpendapat bahwa kebenaran bersifat obyektif dan sebagaimana demikian merupakan pedoman yang tetap bagi semua manusia. ${ }^{1}$ Pada tahun 469 sebelum Masehi, Sokrates telah menyatakan bahwa kebenaran adalah sesuatu yang sifatnya objektif, mutlak, dan tetap yang akhirnya menjadi pedoman bagi semua orang tanpa terkecuali. Menurut Kamus Besar Bahas Indonesia, objektif berarti: mengenai keadaan yang sebenarnya tanpa dipengaruhi pendapat atau pandangan pribadi. ${ }^{2}$ Dengan begitu, kebenaran adalah sama bagi setiap manusia.

Untuk mencapai kebenaran agar mencapai titik sedemikian rupa tersebut, Sokrates dahulu mendidik para pengikutnya agar selalu bertanya tentang berbagai hal terhadap kebenaran itu; apa gunanya, apa tujuannya. Sokrates berkeyakinan kebenaran yang baik itu dapat dicapai dengan ditingkatkannya ilmu pengetahuan, walaupun ilmu pengetahuan dapat menentang adat kebiasaan yang telah berlaku. ${ }^{3}$

Untuk memahami hakikat dari kebenaran itu, merujuk pada pendapat Sokrates, hal terbaik yang dapat dilakukan adalah terus meningkatkan ilmu dengan jalan terus mempertanyakan apa yang telah ada sebelumnya. Inilah yang kemudian menjadi dasar dari berdirinya filsafat ilmu.

Filsafat berkenaan dengan kegiatan perenungan (reflection) tentang apa yang menjadi landasan atau dasar dari berbagai kenyataan (realitas) berikut gejala-gejala atau fenomenanya. Fenomena yang dimaksud adalah segala sesuatu yang dapat ditangkap pancaindera berkenaan dengan realitas alam maupun realitas sosial atau kemasyarakatan, berupa perkembangan, aktivitas dan gerakannya. Atau dengan kata lain fenomena itu adakah segala sesuatu yang terindera dan dan dapat terobservasi; a.l. berupa pemunculan (appeararance), aksi, gerakan, perubahan dan perkembangan dari segala sesuatu tersebut diatas. ${ }^{4}$

Seiring dengan perkembangan waktu, manusia memperoleh sejumlah pengetahuan tentang berbagai hal yang dapat dianggap sebagai awal mula ilmu. Pengetahuan ini meliputi hal-hal yang bersifat fisis maupun non-fisis, yang berjiwa dan tak berjiwa yang terdapaty di bumi dan alam semesta. Objek kajian ilmupun tidak lain adalah realita dan fenomena yang

\footnotetext{
${ }^{1}$ dr Theo Huijbers, Filsafat Hukum dalam Lintasan Sejarah, Penerbit Knisius, 1986, Yogyakarta, hal 21

2 Diunduh dari: http://www.kamusbahasaindonesia.org/objektif/mirip, tanggal 13 September 2012, pukul 14.14 WIB

${ }^{3}$ Theo Hujbers, op. Cit.

${ }^{4}$ Rusadi Kantaprawira, Filsafat dan Penelitian Ilmu-Ilmu Sosial, Penerbit AIPI, Bandung, 2009, hal.1
} 
berhubungan dengan alam semesta dan isinya. Usaha manusia untuk mempertanyakan ilmu inilah yang kemudian disebut sebagai filsafat ilmu. ${ }^{5}$

Filsafat bermula dari aktivitas manusia yang sungguh-sungguh serius dalam memikirkan asal mula dari sesuatu (origin;genesis), kehadiran (existence); dan perkembangannya yang tidak berada dalam jangkauan pengetahuan seseorang. ${ }^{6}$ Dalam proses berpikir tersebut, manusia bisa mendapatkan jawaban sementara atas pertanyaannya, dan bisa saja manusia tidak mendapatkan jawaban sama sekali.

Kegiatan berpikir ini merupakan kegiatan yang tidak bisa terputus oleh rasa puas akan jawaban yang telah ditemukan, karena pada dasarnya manusia adalah bagian yang sangat kecil dari alam semesta. Dalam luasnya semesta dan ilmu pengetahuan, manusia tidak mungkin bisa memahami semua gelaja yang terjadi disekitarnya. Usaha yang paling mendekati yang bisa dilakukan manusia adalah terus bertanya, dan dengan demikian manusia akan semakin memahami gejala-gejala semesta yang menggugah rasa ingin tahunya. Semakin banyak manusia mempertanyakan gejala-gejala semesta tersebut, semakin banyak pula ilmu yang dipahami.

Dalam usaha mempertanyakan tersebut, manusia memiliki keterbatasan berupa waktu dan kemampuan. Inilah yang menyebabkan belum terungkapnya berbagai keingintahuan manusia. Dengan demikian, usaha manusia untuk memahami jawaban atas pertanyaannya adalah sesuatu yang akan bergerak lambat, tetapi apabila terus dilakukan akan menjadi sesuatu yang berkelanjutan dan dapat membangun kemajuan pengetahuan dan ilmu itu sendiri. Rasa tidak cepat puas adalah kunci untuk dipecahkannya berbagai misteri kehidupan. $^{7}$

\section{Universalitas Filsafat Ilmu}

Objek kajian filsafat tidak dapat dibatasi. Segala sesuatu, semua hal dapat dipertanyakan dan digali. ${ }^{8}$ Filsafat merupakan upaya manusia untuk mendekati kebenaran, mencari kebenaran, menemukan hakikat yang terdalam dari sesuatu melalui proses pengerahan segenap kemampuan dan potensi pikiran, peraasaan dan karsanya. Dengan demikian segenap fenomena semesta harus menjadi objek pengamatannya tanpa ada pengecualian. ${ }^{9}$

\footnotetext{
${ }^{5}$ ibid

${ }^{6}$ ibid, hal 8

7 ibid, hal 8-9

8 ibid, ha 11.

${ }^{9}$ ibid, hal 16.
} 
Objek kajian filsafat berupa ilmu yang tidak terbatas itu dapat dikategorikan menjadi dua macam ${ }^{10}$, yaitu:

\section{Objek Material}

Objek material adalah segala sesuatu yang dijadikan sasaran penyelidikan.

Objek material filsafat adalah segala sesuatu yang ada, yang tampak dan tidak tampak. Yng tampak termasuk dalam dunia empiris, yang tidak tampak adalah alam metafisika.

2. Objek Formal

Objek formal adalah metode untuk memahami objek material tersebut.

Objek formal filsafat adalah sudut pandang yang menyeluruh, radikal dan rasional tentang segala yang ada.

Definisi filsafat itu sendiri, menurut Moh. Hatta dan Langeveld adalah tidak perlu diberikan karena setiap orang memiliki titik tekan sendiri dalam definisinya. Karena itu, biarkan saja seseorang meneliti filsafat terlebih dahulu kemudian menimpulkannya sendiri. ${ }^{11}$

Namun, untuk mencapai patokan awal untuk memberi arahan mengenai apa yang akan dibahas, diperlukan adanya definisi tentang apa itu filsafat. Definisi yang diambil disini adalah definisi yang disebutkan oleh Immanuel Kant, yang mengatakan bahwa filsafat ilmu itu dasar dari segala pengetahuan, yang mencakup didalamnya empat persoalan, ${ }^{12}$ yaitu:

1. Apakah yang dapat kita ketahui? (Dijawab oleh metafisika)

2. Apakah yang boleh kita kerjakan? (Dijawab oleh etika)

3. Sampai dimanakah pengharapan kita? (Dijawab oleh agama)

4. Apakah yang dinamakan manusia? (Dijawab oleh antropolog)

Seorang filsuf bernama Sidi Gazalba juga mengemukakan tiga ciri pokok dalam filsafat ${ }^{13}$, yaitu:

1. Adanya unsur berpikir yang dalam hal ini menggunakan akal.

2. Adanya unsur tujuan yang ingin dicapai melalui berpikir tersebut.

3. Adanya unsur ciri yang terdapat dalam pikiran tersebut, yakni mendalam.

Dengan demikian terlihat bahwa inti dari filsafat dalah upaya secara sungguh-sungguh dengan menggunakan akal pikiran sebagai alat utamanya, untuk menemukakakn hakikat segala sesuatu yang berhubungan dengan ilmu. ${ }^{14}$

\footnotetext{
${ }^{10}$ Prof. Dr. Amal Bakhtiar, M.A, Filsafat ilmu, PT Raja Grafindo Persada, Jakarta, 2011, hal 1

11 ibid, hal 6

12 ibid, hal8

${ }^{13}$ ibid, hal 9

${ }^{14} \mathrm{ibid}$, hal 10
} 
Filsafat ilmu merupakan telaah secara filsafat yang ingin menjawab beberapa pertanyaan mengenai hakekat ilmu seperti ${ }^{15}$ :

1. Obyek mana yang ditelaah ilmu? Ujud hakiki obyek? Hubungan obyek dengan tangkapan manusia (berfikir, merasa, mengindera( yang membuahkan pengetahuan).

2. Bagaimana proses yang memungkinkan ditimba pengetahuan yang berupa ilmu? Bagainama prosedurnya. ? hal-hal apa yang harus diperhatikan agar kita mendapat pengetahuan yang benar, Apa yang disebut kebenaran itu sendiri? Apa kriterianya? Cara dan tehnik sarana yang membantu kita mendapat pengetahuan yang berupa ilmu

3. Untuk apa pengetahuan yang berupa ilmu itu dipergunakan? Bagaimana kaitan antara cara penggunaan tersebut dengan kaidah-kaidah moral? Bagaimana penentuan obyek yang ditelaah berdasarkan pilihan-pilihan moral? Bagaimana kaitan antara tehnik prosedural yang merupakan operasinal metode ilmiah dengan norma-norma moral/ profesional.

Sementara ilmu itu sendiri, menurut Amsal Bakhtiar, ilmu adalah sebagian pengetahuan yang mempunyai ciri, tanda, syarat tertentu, yaitu sistematik, rasional, empiris, universal, objektif, dapat diukur, terbuka, dan kumulatif (bersusun timbun). ${ }^{16}$

Amsal Bakhtiar juga menyimpulkan bahwa filsafat ilmu merupakan kajian secara mendalam tentang dasar-dasar ilmu, sehingga filsafat ilmu mempunyai tujuan sebagai berikut ${ }^{17}$ :

1. Mendalami unsur-unsur pokok ilmu, sehingga secara menyeluruh kita dapat memahami sumber, hakikat dan tujuan ilmu.

2. Memahami sejarah pertumbuhan, perkembangan dan kemajuan ilmu di berbagai bidang, sehingga kita mendapat gambaran tentang proses ilmu kontemporer secara historis.

3. Menjadi pedoman bagi para dosen dan mahasiswa dalam mendalami studi di perguruan tinggi, terutama untuk membedakan persoalan ilmiah dan nonilmiah.

\footnotetext{
15 Jujun S Suriasumantri, Filsafat ilmu Sebuah Pengantar Populer, Pustaka sinar Harapan jakarta 1993 hal $33-34$

${ }^{16}$ Amal Bakhtiar, op.cit., hal 16

${ }^{17}$ Amal Bakhtiar, op.cit., hal 20
} 
4. Mendorong para calon ilmuwan dan ilmuwan untuk konsisten dalam mendalami ilmu dan mengembangkannya.

5. Mempertegas bahwa dalam persoalan sumber dan tujuan antara ilmu dan agama tidak ada pertentangan.

Dan menurut Agraha Suhandi, adanya filsafat ilmu berfungsi sebagai:

1. Sebagai alat mencari kebenaran dari segala fenomena yang ada.

2. Mempertahankan, menunjang dan melawan atau berdiri netral terhadap pandangan filsafat lainnya.

3. Memberikan pengertian tentang cara hidup, pandangan hidup dan pandangan dunia.

4. Memberikan ajaran tentang moral dan etika yang berguna dalam kehidupan

5. Menjadi sumber inspirasi dan pedoman untuk kehidupan dalam berbagai aspek kehidupan itu sendiri, seperti ekonomi, politik, hukum dan sebagainya.

\section{Filsafat Ilmu dan Ilmu Hukum}

Manusia adalah mahluk sosial yang mempunyai kecenderungan untuk hidup berkelompok. Selama manusia hidup sendiri, tidak akan timbul persoalan tentang hak atau hukum, tidak membutuhkan hukum dan bebas melakukan apapun sekehendak hatinya. Situasi akan berubah ketika dalam kehidupannya muncul individu lain. Dalam jumlah kumpulan individu yang masih sedikit, hubungan antar manusia masih amat sederhana. Kehidupan tersebut masih dapat berjalan tanpa aturan-aturan perilaku yang dirumuskan secara eksplisit dan amsih dirasakan nyaman tanpa gangguan yang berarti.

Kehidupan seperti ini lama kelamaan akan berubah apabila jumlah individu dalam kumpulan tersebut semakin bertambah. Kumpulan yang semakin berkembang itu membutuhkan pengaturan, apa yang boleh dan tidak boleh dilakukan dalam pergaulan mereka, serta ketentuan-ketentuan yang mengatur hubungan antar individu tersebut. Timbulah apa yang dinamakan hukum, yaitu aturan-aturan hidup yang mengatur hubungan antar manusia yang hidup dalam suatu kelompok masyarakat . Aturan-aturan itu mengikat mereka karena mereka sepakat untuk tunduk atau terikat dalam aturan tersebut. ${ }^{18}$

\footnotetext{
${ }^{18}$ Mochtar Kusumaatmadja dan Arief Sidharta, Pengantar Ilmu Hukum, Suatu Pengantar Pertama Ruang Lingkup Berlakunya Ilmu Hukum Buku I, Penerbit Alumni, Bandung, 2000, hal 12-14
} 
Sementara itu, pembelajaran mengenai hukum adalah pembelajaran cara berpikir yuridis. Kegiatan mempelajari hukum lebih banyak merupakan usaha untuk menguasai bahasa hukum, karena didalam bahasa hukum itulah terletak cara berpikir yuridis. ${ }^{19}$

Aturan-aturan dan keputusan yang ada dimasyarakt, seperti yang disebutkan diatas, diserahkan kepada yang berwenang yaitu pemerintah, untuk kemudian dituangkan kedalam rumusan-rumusan tertentu. Rumusan ini mewujudkan inti dari sistem hukum yang ada dalam masyarakat agar menjadi acuan orang-orang dalam menjalani kehidupan sehari-hari. Disinilah muncul peranan dari bahasa untuk hukum. Tanpa bahasa, hukum mustahil untuk dipahami. Hukum positif yang ada dalam masyarakat ada karena kenyataan bahwa manusia memiliki bahasa. ${ }^{20}$

Fungsi Hukum secara garis besar adalah ${ }^{21}$ :

1. Sebagai alat pengendalian sosial (a tool of social control).

2. Sebagai alat untuk mengubah masyarakat ( a tool of social engineering).

3. Sebagai alat ketertiban dan pengaturan masyarakat.

4. Sebagai sarana untuk mewujudkan keadilan sosial lahir dan batin.

5. Sebagai sarana penggerak pembangunan.

6. Sebagai fungsi kritis dalam hukum.

7. Sebagai fungsi pengayoman.

8. Sebagai alat politik.

Sementara filsafat modern, bertolak dari hubungan erat antara berpikir dan bahasa. ${ }^{22}$ Manusia dapat meneliti apa yang dia atau orang lain pikirkan, karena manusia telah menyampaikan pikiran tersebut dengan berbicara dan menulis. Pikrian tidak dapat disampaikan apabila manusia tidak menuangkannya dalam pernyataan dan tulisan. Barulah setelah berbicara dan menulis, pikiran tersebut dapat "seolah-olah" didengar dan dibaca. Bahasa memberikan bentuk kepada pikiran manusia agar pikiran tersebut dapat diobservasi dan diteliti.

Kehidupan masyarakat yang diharapkan akan tertib dan teratur itu memerlukan adanya tatanan atau norma-norma. Tatanan ini bukan merupakan suatu konsep tunggal yang berdiri sendiri, melainkan merupakan suatu kompleksitas tersendiri, yang didalamnya tersusun dari sub-sub tatanan. Satjipto Rahardjo mengatakan bahwa sub-sub tatanan itu

\footnotetext{
${ }^{19}$ J.J.H. Bruggink, Refleksi Tentang Hukum, PT. Citra Aditya Bakti, Bandung, 1999, hal 1

${ }^{20}$ Mochtar Kusumaatmadja dan Arief Sidharta, op.cit., hal 4

${ }^{21}$ Diunduh dari www.badilag.net_data_ARTIKEL_Filsafat Hukum dan Perannya dalam Pembentukan Hukum Di Indonesia.pdf tanggal 18 September 2012 pukul 20.00 WIB

${ }^{22}$ Mochtar Kusumaatmadja dan Arief Sidharta , op.cit., hal 5
} 
adalah kebiasaan, hukum dan kesusilaan. Ketiga tatanan inilah yang membentuk ketertiban dalam masyarakat.

Secara spesifik, hukum, sebagai bagian dari tatanan diatas, dibuat secara sengaja oleh suatu badan pelengkap dalam masyarakat yang khusus ditugasi untuk mengawasi dan membuat hukum tersebut. Norma hukum secara sadar dan sengaja dibuat untuk menegakkan ketertiban. ${ }^{23}$ Norma hukum lahir dari kehendak manusia untuk membentuk suatu masyarakat yang ideal. Disinilah filsafat berperan, dalam merancang dan membentuk norma yang utopis, yang dapat mendukung ketertiban masyarakat secara nyata. Unsur ideal ketertiban tersebut digunakan untuk menyokong masyarakat secara sosiologis. Hal ini dapat dilihat dari bagan dibawah ini: ${ }^{24}$
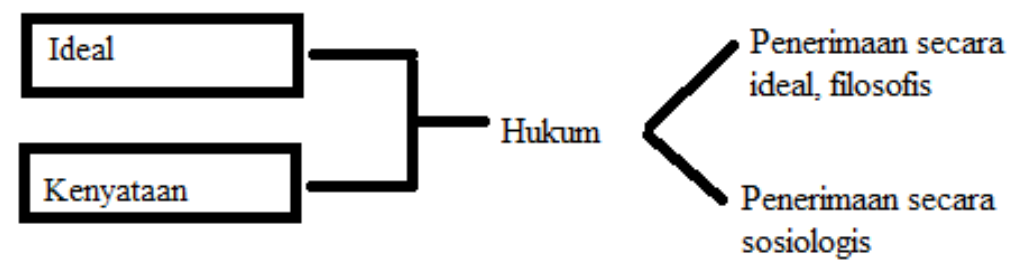

Hukum, dalam ranah falsafati, menurut Dr. Theo Huijbers dapat dipelajari dalam 2 tingkat ${ }^{25}$, yaitu:

1. Sebagai hukum yang berkaitan dengan manusia sebagai manusia.

Manusia yang dimaksud disini itu bukan manusia secara abstrak, melainkan secara konkret sebagai pribadi. Dengan menyoroti hukum dalam hubungan dengan manusia secara demikian sudah kentara bahwa manusia merupakan subjek hukum, bukan sebab ia berpautan dengan sekelompok orang lain berkat keturunan, warna kulit, agama dan sebagainya, melainkan hanya sebab ia manusia.

2. Sebagai hukum yang berkaitan dengan negara.

Negara bukanlah sebagai subjek hukum, tetapi sejak zaman modern negara merupakan instansi yang tak bersyarat bagi ditetapkannya dan dipertahankannya hukum dalam arti yuridis. Dengan merenungkan hukum sebagai aturan negara dapat diperoleh kemampuan untuk menilai suatu sistem hukum tertentu.

\footnotetext{
${ }^{23}$ Satjipto Rahardjo, Ilmu Hukum, PT Citra Aditya Bakti,Bandung, 2000, hal15

24 ibid, hal 16

${ }^{25}$ Theo Huijbers, Filsafat Hukum, Penerbit Kanisius, Yogyakarta, 1995, hal 19
} 
Dari pandangan diatas, Dr. Theo Huijber berpandangan bahwa saat hukum menjadi objek filsafat, yang akan dicari adalah makna hukum dalam kehidupan sehari-hari manusia. ${ }^{26}$ Manusia sebagai subjek hukum dilihat sebagai manusia seutuhnya, bebas dari paradigma bahwa manusia itu memiliki ciri yang berbeda dalam hal ras, agama dan lain sebagainya. Beliau ingin menegaskan bahwa filsafat melihat bahwa manusia tidak memiliki perbedaan dalam mata hukum, bahwa sebagai subjek hukum ia adalah sederajat.

Selain itu Dr. Theo Huijber juga memposisikan filsafat dalam meneliti negara dan kaitannya dengan sistem hukum. Hukum adalah aturan yang berlaku dalam negara. Tanpa negara, hukum menjadi tidak berlaku dan tidak akan ada artinya. Sistem hukum baru dapat dinilai apabila hukum dipahami sebagai aturan negara, kaidah secara keseluruhan yang tidak dapat dilihat secara terpisah-pisah. Kaidah yang membentuk sistem itulah yang turut mengatur jalannya pemerintahan tersebut.

Dalam bidang studi magister ilmu hukum sendiri, terlihat bahwa bidang filsafat ilmu adalah bidang studi yang cukup penting untuk diberikan. Ini terlihat dari usaha mempersiapkan mahasiswa pascasarjana dalam menghadapi perkuliahan dengan terlebih dahulu memberikan kuliah filsafat ilmu ini. Ibaratnya, filsafat ilmu diharapkan menjadi gerbang pengantar pengertian para mahasiswa tentang cara memahami ilmu yang lebih baik pada tingkat magister hukum.

Bertolak dari pendapat Ismaun yang mengatakan bahwa filsafat ilmu dipelajari untuk memberikan landasan filosofik dalam memahami berbagai konsep dan teori sesuatu disiplin ilmu dan membekali kemampuan untuk membangun teori ilmiah, sekiranya begitu jugalah hakikat filsafat ilmu dalam mempelajari ilmu hukum. Filsafat ilmu bertujuan untuk membahtu memahami konsep dan teori ilmu hukum dan membantu membangun teori ilmiah. Serta, seperti yang telah dijelaskan diatas, filsafat membantu para ilmuan hukum untuk memahami bahasa hukum, memberikan pemahaman tentang konsep hukum yang ada dalam pikiran manusia dan memberikan bentuk kepada konsep-konsep tersebut kedalam undang-undang dan peraturan tertulis.

Selain itu, filsafat ilmu juga berfungsi dalam proses manusia dalam mencari keadilan. Keadilan juga merupakan dari tujuan adanya ilmu hukum. Proses reformasi menunjukkan bahwa hukum harus ditegakkan demi terwujudnya supremasi hukum dalam rangka menegakkan kebenaran dan keadilan sesuai dengan tujuan hukum: Ketertiban, keamanan, ketentraman, kedamaian, kesejahteraan, kebenaran dan keadilan. Keadilan berkaitan erat

\footnotetext{
${ }^{26}$ ibid, hal 18
} 
dengan pendistribusian hak dan kewajiban, hak yang bersifat mendasar sebagai anugerah Ilahi sesuai dengan hak asasinya yaitu hak yang dimiliki seseorang sejak lahir dan tidak dapat diganggu gugat. Keadilan merupakan salah satu tujuan sepanjang perjalanan sejarah filsafat hukum. Keadilan adalah kehendak yang ajeg, tetap untuk memberikan kepasa siapapun sesuai dengan pertumbuhan dan perkembangan masyarakat dan tuntutan jaman. ${ }^{27}$ Korelasi antara filsafat, hukum dan keadilan sangat erat, karena terjadi tali temali antara kearifan, norma dan keseimbangan hak dan kewajiban. Hukum tidak dapat dipisahkan dengan masyarakat dan negara, materi hukum digali, dibuat dari nilai-nilai yang terkandung dalam bumi pertiwi yang berupa kesadaran dan cita hukum (rechtidee), cita moral, kemerdekaan individu dan bangsa, perikemanusiaan, perdamaian, cita politik dan tujuan negara. Hukum mencerminkan nilai hidup yang ada dalam masyarakat yang mempunyai kekuatan berlaku secara yuridis, sosiologis dan filosofis. Tata rakit antara filsafat, hukum dan keadilan, dengan filsafat sebagai induk ilmu (mother of science), adalah untuk mencari jalan keluar dari belenggu kehidupan secara rational dengan menggunakan hukum yang berlaku untuk mencapai keadilan dalam hidupnya. ${ }^{28}$

\section{Simpulan}

Kegunaan dari dipelajarinya filsafat ilmu dalam bidang hukum adalah untuk mengkaji moral dalam ilmu hukum. Azas moral mewarnai perilaku ilmuwan dalam pemilihan objek telaah ilmu maupun dalam menemukan kebenaran ilmiah. Moral merupakan suatu baseline yang penting untuk dimiliki oleh setiap ilmuan hukum, demi merangsang kepekaan terhadap ketidakadilan dan menegakkan fungsi hukum itu sendiri. Jujun Suria Sumantri memberikan pandangan mengenai hubungan ilmu dan moral dengan mempertimbangkan dimensi filosofis ilmu, yaitu ${ }^{29}$ :

1. Untuk mendapatkan pengertian yang benar mengenai kaitan antara ilmu dan moral maka pembahasan masalah ini harusdidekati dari segi-segi yang lebih terperinci yaitu segi ontologi,epistemologi, dan aksiologi.

2. Menafsirkan hakikat ilmu dan moral sebaiknya memperhitungkan faktor sejarah, baik sejarah perkembangan ilmu itu sendiri, maupun penggunaan ilmu dalam lingkup perjalanan sejarah kemanusiaan.

\footnotetext{
${ }^{27}$ Arry Sukowathy, Peran dan Relevansi Filsafat Hukum, Jurnal Filsafat, Desember 2003, Jilid 35, Nomor 3 , hal 292

${ }^{28}$ ibid, hal 293

${ }^{29}$ Jujun S Suriasumantri, op.cit., hal 15-16 
3. Secara ontologis dalam pemilihan wujud yang akan dijadikan objek penelaahannya (objek ontologis / objek formal) ilmu dibimbing oleh kaidah moral yang berazaskan tidak mengubah kodrat manusia, tidak merendahkan martabat manusia, dan tidak mencampuri masalah kehidupan.

4. Secara epistemologis, upaya ilmiah tercermin dalam metoda keilmuan yang berporoskan proses logiko-hipotetiko-verifikatif dengan kaidah moral yang berazaskan menemukan kebenaran, yang dilakukan dengan penuh kejujuran, tanpa kepentingan langsung tertentu dan berdasarkan kekuatan argumentasi an sich.

5. Secara aksiologis ilmu harus digunakan dan dimanfaatkan untuk kemaslahatan manusia dengan jalan meningkatkan taraf hidupnya dan dengan memperhatikan kodrat manusia, martabat manusia, dan keseimbangan / kelestarian alam. Upaya ilmiah ini dilakukan dengan penggunaan dan pemanfaatan pengetahuan ilmiah secara komunal universal.

\section{Daftar Pustaka}

\section{Buku}

Amal Bakhtiar, Filsafat ilmu,, PT Raja Grafindo Persada, Jakarta, 2011

J.J.H. Bruggink, Refleksi Tentang Hukum, PT. Citra Aditya Bakti, Bandung, 1999

Jujun S Suriasumantri, Filsafat ilmu Sebuah Pengantar Populer, Pustaka sinar Harapan, Jakarta 1993

Mochtar Kusumaatmadja dan Arief Sidharta, Pengantar Ilmu Hukum, Suatu Pengantar Pertama Ruang Lingkup Berlakunya Ilmu Hukum Buku I, Penerbit Alumni, Bandung, 2000

Rusadi Kantaprawira, Filsafat dan Penelitian Ilmu-Ilmu Sosial, Penerbit AIPI, Bandung, 2009

Satjipto Rahardjo, Ilmu Hukum, PT Citra Aditya Bakti, Bandung, 2000

Theo Huijbers, Filsafat Hukum dalam Lintasan Sejarah, Penerbit Knisius, Yogyakarta, 1986

Theo Huijbers , Filsafat Hukum, Penerbit Kanisius, Yogyakarta, 1995

\section{Jurnal}

Arry Sukowathy, Peran dan Relevansi Filsafat Hukum, Jurnal Filsafat, Desember 2003, Jilid 35, Nomor 3

\section{Website}

http://www.badilag.net_data_ARTIKEL_Filsafat Hukum dan Perannya dalam Pembentukan Hukum Di Indonesia.pdf (diakses tanggal 6 Juni 2019) 